\title{
0071. The association between meteoropathy, depression, hopelessness and quality of life in medication-overuse headache patients
}

\author{
Samantha Bellini, Monica Migliorati, Federica Ricci, Denise Erbuto, Maurizio Pompili* \\ From Abstracts from the 1st Joint ANIRCEF-SISC Congress \\ Rome, Italy. 29-31 October 2015
}

\section{Background}

Medication-overuse headache $(\mathrm{MOH})$ is one of the most common forms of chronic daily headache $(\mathrm{CDH})$ [1], with a prevalence in the adult general population of $1 \%-2 \%$ [2]. $\mathrm{MOH}$ is often comorbid with emotional disturbances and disordered personality traits. The aim of the present study was to determine whether depression, hopelessness and quality of life were associated with meteoropathy in $\mathrm{MOH}$ patients. The most frequent symptom of meteoropathy is the exacerbation of acute or chronic forms of pain in many parts of the body, in and of itself inflamed and/or degenerated.

\section{Materials and methods}

Participants were 203 consecutive adult outpatients, of which 165 females (81.3\%), admitted to the local Headache Centre of the Sant'Andrea Hospital in Rome, Italy. Inclusion criteria were a diagnosis of $\mathrm{MOH}$, and an age of 18 years or older. Exclusion criteria were comorbidity with major disorders of the central nervous system, delirium and/or any condition affecting the patient's ability to complete the assessment. The average age of participants was $46.99 \pm 11.99$. Patients participated voluntarily in the study, and each subject provided written informed consent. Patients were administered the BDI II, BHS, Q-LES-Q and the METEO-Q.

\section{Results}

The results showed middle-high levels of meteoropathy in our sample. Men showed higher level of meteoropathy than female. The intensity of meteoropathy correlates significantly with the levels of depression $(r=.253 ; \mathrm{p}<0.01)$,

\footnotetext{
* Correspondence: maurizio.pompili@uniroma1.it

Department of Neurosciences Suicide Prevention Centre, Sapienza University of Rome, Rome, Italy
}

Conflict of Interest

The authors report no conflicts of interest.

\section{Acknowledgements}

This study was not supported financially by any grants.

Published: 28 September 2015 


\section{References}

1. Dong Z, Di H, Dai W, Liang J, Pan M, Zhang M, et al: Application of ICHD-II criteria in a headache clinic of China. PLoS One 2012, 7:e50898.

2. Aaseth $K$, Grande RB, Kvaerner K, Gulbrandsen P, Lundqvist C, Russell MB: Prevalence of secondary chronic headaches in a population-based sample of 30-44-year-old persons. The Akershus study of chronic headache. Cephalalgia 2008, 28:705-13.

doi:10.1186/1129-2377-16-S1-A50

Cite this article as: Bellini et al: O071. The association between meteoropathy, depression, hopelessness and quality of life in medication-overuse headache patients. The Journal of Headache and Pain 2015 16(Suppl 1):A50.

\section{Submit your manuscript to a SpringerOpen ${ }^{\mathcal{O}}$ journal and benefit from:}

- Convenient online submission

- Rigorous peer review

- Immediate publication on acceptance

- Open access: articles freely available online

- High visibility within the field

- Retaining the copyright to your article

Submit your next manuscript at $\gg$ springeropen.com 